Vol. 6, No. 2, 2020

Andrii Kravchuk $^{4}$, Tetiana Pavlychuk ${ }^{5}$, Viktor Antonyuk ${ }^{6}$, Kateryna Avramchuk ${ }^{7}$

${ }^{1}$ Department of Composite Materials, I.M. Frantsevich Institute for Problems of Materials Science of the National Academy of Sciences of Ukraine, Ukraine, Kyiv, 3 Akademika Krzhyzhanovs'koho Street, E-mail: otdel38@bigmir.net, Scopus Author ID 6603960472

${ }^{2}$ Department of Composite Materials, I.M. Frantsevich Institute for Problems of Materials Science of the National Academy of Sciences of Ukraine, Ukraine, Kyiv, 3 Akademika Krzhyzhanovs'koho Street, E-mail: otdel38@bigmir.net, Scopus Author ID 6507774710

${ }^{3}$ Department of Composite Materials, I.M. Frantsevich Institute for Problems of Materials Science of the National Academy of Sciences of Ukraine, Ukraine, Kyiv, 3 Akademika Krzhyzhanovs'koho Street, E-mail: y_fedoran@rambler.ru, Scopus Author ID 55990646300

${ }^{4}$ Department of Composite Materials, I.M. Frantsevich Institute for Problems of Materials Science of the National Academy of Sciences of Ukraine, Ukraine, Kyiv, 3 Akademika Krzhyzhanovs'koho Street, E-mail: otdel38@bigmir.net, Scopus Author ID 36473380500

${ }^{5}$ Department of Composite Materials, I.M. Frantsevich Institute for Problems of Materials Science of the National Academy of Sciences of Ukraine, Ukraine, Kyiv, 3 Akademika Krzhyzhanovs'koho Street, E-mail: otdel38@bigmir.net, Scopus Author ID 57215871631, ORCID 0000-0003-2962-4223

${ }^{6}$ Department of Instrumentation Design and Engineering, National Technical University of Ukraine "Igor Sikorsky Kyiv Polytechnic Institute", Ukraine, Kyiv, 37 Peremohy Avenue, E-mail: vp@kpi.ua, victor.antoniuk@gmail.com, Scopus Author ID 6603705354, ORCID 0000-0003-0690-2411

${ }^{7}$ Department of Instrumentation Design and Engineering, National Technical University of Ukraine "Igor Sikorsky Kyiv Polytechnic Institute", Ukraine, Kyiv, 37 Peremohy Avenue, E-mail: katya.avramchuk.24@gmail.com, Scopus Author ID 57218376704

\title{
INFLUENCE OF DIAMOND COMPONENT BASED ON WURTZITE BORON NITRIDE ON WEAR RESISTANCE OF CUTTING TOOL
}

Received: August 10, 2020 / Revised: September 24, 2020 / Accepted: September 30, 2020

(C) Volkogon V., Avramchuk S., Fedoran Yu., Kravchuk A., Pavlychuk T., Antonyuk V., Avramchuk K., 2020

Abstract. The article is devoted to the study of the influence of the diamond component in a composite superhard material based on wurtzite boron nitride on the stability of the tool during turning of hardened steels in the mode of smooth turning and when processing intermittent surfaces. The aim of the work is to study the influence of the content of the diamond component in the composite superhard material based on wurtzite boron nitride on the stability of the tool. Based on the analysis of the main patterns of changes in the coefficient of friction depending on various factors, the evaluation of composites containing diamonds of different dispersion in comparison with other materials of this class. The results of the study of the technical level of composite polycrystalline superhard materials based on wurtzite boron nitride of different composition and determination of the efficiency of their use as a cutting tool in the machining of hardened steels are presented. The intensity of wear of composites in the cutting tool during processing of hardened steels is experimentally determined. It is established that the presence of a diamond component in the composite significantly affects the stability of the tool in the conditions of smooth turning due to heat dissipation in contact with the processed material. In the processing of hardened steels with the presence of shock loads, the phase state of the matrix component of the composite plays a decisive role. The obtained research results make it possible to determine the optimal composition and conditions for obtaining a composite material of the system "boron nitride - diamond", which provides the most effective application of the cutting tool in practice.

Keywords: boron nitride, diamond, composite, friction coefficient, cutting ability, wear resistance. 


\section{Volodymyr Volkogon, Svitlana Avramchuk, Yuriy Fedoran, Andrii Kravchuk, et al.}

\section{Introduction}

Superhard tool materials play an important role in the production processes of the machine-building industry, they determine the development of new and improvement of known methods of forming the working surfaces of products. Their application determines the possibility of productive machining of the most high-strength and difficult-to-process structural and functional materials, the share of which in the new technology is constantly growing [1], [2]. At the same time the processes of finishing machining deserve great attention. Trends in the development of machining processes are associated with the targeted provision of maximum results with minimum costs [3], [4].

With regard to finishing technologies, it is characterized not only by the productivity of the process, but also by the need to ensure the formation in the surface layers of products of the state, which would ensure their maximum efficiency during operation [5]-[8]. The role of the tool in solving the problems of increasing production efficiency is one of the most important in terms of efficiency in mechanical engineering of particular interest are tools made of polycrystalline superhard materials (PSHM) composites based on dense modifications of boron nitride and diamond [9]-[11].

Cutting tools with PSHM effectively process materials of high hardness up to $60 \ldots 65 \mathrm{HRC}$. The use of cutters with PSHM on the basis of dense modifications of boron nitride (cubic and wurtzite) in finishing operations in the processing of high-hard materials (hardened steels, high-strength and bleached cast iron) makes it possible to stably obtain surfaces with a roughness $R a=0.2 \ldots 1.0 \mu \mathrm{m}$, and in some cases replace the grinding operation [7], [12]-[15].

Modern finishing processes are based on the results of numerous scientific studies of patterns of mechanical and physical-mechanical phenomena in the contact zone of the tool and the product, taking into account the action and destruction of the tool, the state of the surface layer of the workpiece. The key role in the technology is played by the tool, namely the material of the cutting element [10], [16]-[22].

Questions of use of new materials and constructive decisions at creation of cutting tools are actual and need constant development.

\section{Problem Statement}

The aim of this work is to study the effect of the content of the diamond component in the composite superhard material based on wurtzite boron nitride on the stability of the tool.

\section{Review of Modern Information Sources on the Subject of the Paper}

High hardness and strength of superhard materials based on wurtzite boron nitride indicate the possibility of their effective application in practice - in the machining of a wide range of steels and alloys, as well as in highly loaded friction pairs [4]-[7], [23]. Currently, there is a wide range of instrumental polycrystalline superhard materials (PSHM) based on wurtzite boron nitride (composite 10, sumiboron, wurtzin, etc.), which differ in physical and mechanical properties related to the production technology, as well as the composition and structure of the material. At the same time, the high physical and mechanical properties of composites expand the possibilities of creating effective and highly productive technologies of mechanical processing and new areas of application [13], [16], [17].

The study of wear characteristics and durability of tool materials is one of the central issues in the evaluation of new tool material. When determining the wear resistance and areas of effective application of new tool material, it is necessary to compare its performance with this indicator for similar tool superhard materials, which are widespread and used in practice [7], [8], [14]-[18], [22]-[24]. They include such indicators as the productivity of the cutting process, the value of the maximum cutting path with optimal wear of the cutter, as well as the efficiency of application with high quality of the process [6]-[8], [22]-[26].

\section{Experimental Methodology}

Samples of the processed material had constantly monitored mechanical characteristics. To determine the wear of the incisors used special microscopes - instrumental microscope VIM-1 and metallographic microscope MIM-8M. 


\section{Influence of Diamond Component Based on Wurtzite Boron Nitride on Wear Resistance of ...}

Sintered polycrystals of these materials were machined on planes and contours on a universal sharpening machine mod. SV642 using a special device that provides surface preparation from a single installation of the sample. The device mounted on the base of the machine is a mandrel on which at a distance of $35 . .40 \mathrm{~mm}$ coaxially installed diamond cup circles on an organic bond with different abrasive grains $-80 / 63$ (rough surface preparation) and 14/10 (finishing operation).

The processed sample was clamped in three-turn vices mounted on the machine table. After finishing the flat surfaces, the surfaces were finished on a cast iron washer, which was pre-carved with diamond powder with a grain size of $5 / 3$. Contour machining was performed on a circular grinding machine mod. ZK12 in a special device. In the processed form, the plates were round with a diameter of $D=7 \mathrm{~mm}$, thickness $S=3.18 \mathrm{~mm}$ with a reinforcing chamfer $0.2 \times 20^{\circ}$ on the cutting edge, the designation of the plate RNMN0703M0. For fastening of cutting plates at tests used turning right through cutters with the $\Gamma$-shaped clamp. The plate in the cutter was clamped at an angle of $6^{\circ}$, which provided the geometry of its cutting part $\alpha_{\text {longit }}=-\gamma_{\text {longit }}=6^{\circ}$.

The study of the cutting properties of the plates was carried out on a universal lathe of model 16K20. The processed material during the tests was steel 100Cr6 DIN 17230 hardened to $61 \ldots 63 \mathrm{HRC}$ in the form of a cylindrical workpiece with a diameter of $88 \ldots 95 \mathrm{~mm}$ and a length of $300 \mathrm{~mm}$. When testing the resistance of polycrystalline superhard materials to impact loads in the processing process used blanks, on the side surface of which was made a longitudinal groove width of $4 \mathrm{~mm}$.

The tests were performed with the following modes - cutting speed $V-75 \mathrm{~m} / \mathrm{min}$ and $150 \mathrm{~m} / \mathrm{min}$, cutting depth $t=0.2 \mathrm{~mm} ; 0.5 \mathrm{~mm}$ and feed $S=0.12 \mathrm{~mm} / \mathrm{rev} ; 0.15 \mathrm{~mm} / \mathrm{rev}$. The criterion for the stability of the tool when turning hardened steel was taken as the amount of wear of the cutting plate made of composite material on the rear surface $h_{r}=0.4 \mathrm{~mm}$.

\section{Presentation of the Main Material}

The cutting process is significantly influenced by contact phenomena that occur as a result of the interaction of the tool with the surface of the workpiece [5], [11]-[15]. The physical features of the machining process are determined by the friction between the workpiece material and the cutter material, the role of which is especially noticeable in the process of cutting with small cross sections of chips, which occurs during semi-finishing and finishing turning with superhard materials [7], [13], [25]-[27].

Determination of the technical level of the developed composite PSHM and their suitability for use as a cutting tool was carried out by studying the cutting properties of composites in the turning of hardened steel 100Cr6 DIN 17230 (HRC 61...63). Experimental studies were performed according to the scheme of external longitudinal turning of a cylindrical workpiece such as a sleeve hardened from steel $100 \mathrm{Cr} 6$ DIN 17230 cutter with a replaceable metal cutting plate made of superhard material based on boron nitride.

For tests used experimental samples of composite polycrystalline superhard materials based on the system "wurtzite boron nitride-diamond", which contained $10 \mathrm{wt} \%$ diamond component of three types:

- type 1 - composite material based on $\mathrm{BN}_{\mathrm{w}}$ which included diamonds of static synthesis $0.1 / 0 \mu \mathrm{m}$, sintered at $T=1600^{\circ} \mathrm{C}$;

- type 2 - composite material of the same composition, sintered at $T=2000^{\circ} \mathrm{C}$;

- type 3 - Composite material based on wurtzite boron nitride and diamonds of static synthesis $10 / 7 \mu \mathrm{m}$, sintered at $T=1800^{\circ} \mathrm{C}$.

In accordance with the increase in the temperature parameters of obtaining composites, the phase composition of the matrix material based on boron nitride changed in the direction of increasing the content of sphalerite boron nitride [28], [29].

If at $T=1600^{\circ} \mathrm{C}$ the content of sphalerite boron nitride was $60 \%$ vol. then at $T=1800^{\circ} \mathrm{C}$ wurtzite boron nitride was completely converted into $\mathrm{BN}_{\text {sph. }}$. Further increase of the sintering temperature to $T=2000^{\circ} \mathrm{C}$ promotes collective recrystallization of sphalerite boron nitride, while in the system with diamond there is an interaction of the components of the mixture - "boron nitride - diamond" [30], [31].

Fig. 1 shows an electron microscopic image of the grain structure and microelectrongram (MEG) of a composite material based on wurtzite boron nitride and diamonds, with the presence of solid boundaries 
"diamond - diamond-like phase of boron nitride", between the diamond particles and the matrix component there is a layer with a thin boundary conjugation with a diamond.

The thickness of such layers varies, both for individual diamond particles and for the volume of the samples, and is generally $5 \ldots 200 \mathrm{~nm}$. This state of the structure of the composite material affects its tribotechnical and physico-mechanical characteristics [27]-[30].

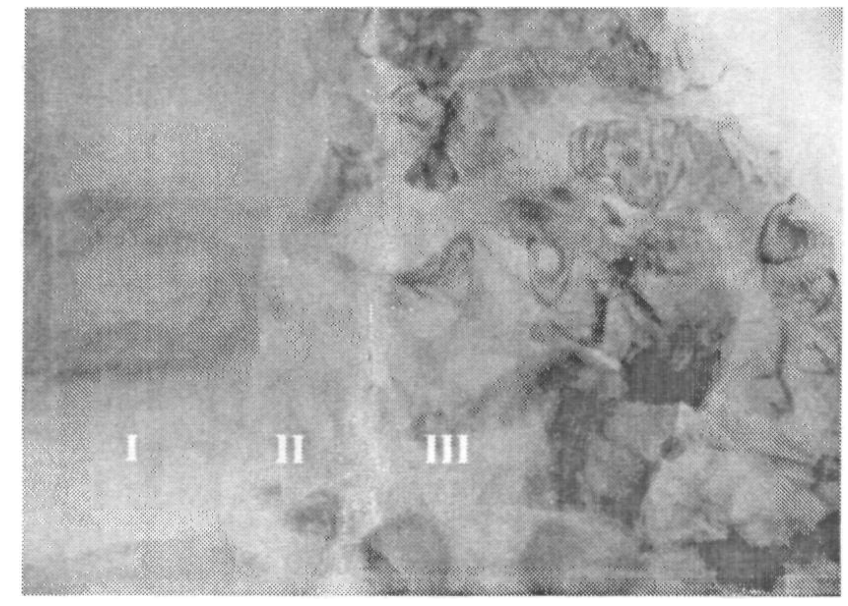

a

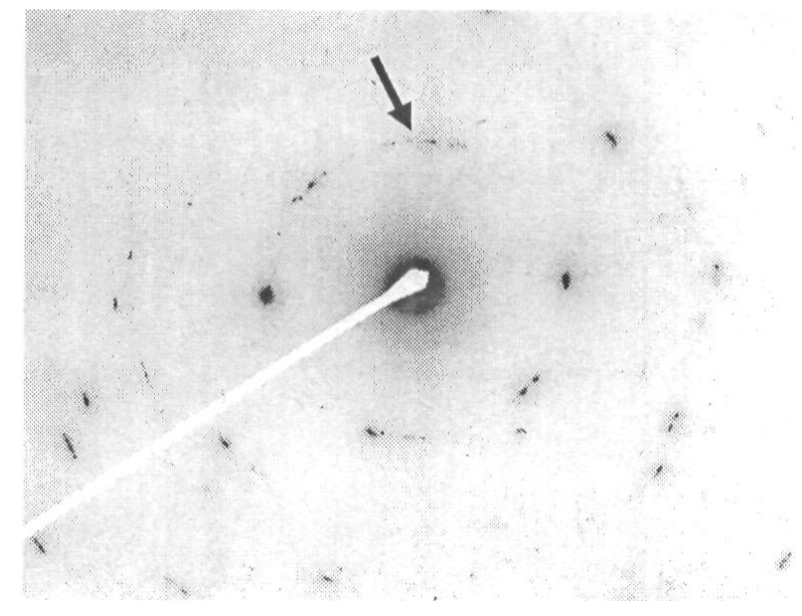

b

Fig. 1. Image on the lumen (a) and MEG from areas (I + II) (b) of the microstructure of the composite "wurtzite boron nitride - diamond": I - diamond; II - layer; III - matrix BN

To study the processes occurring in the contact zone of the tool made of composite material of the system "wurtzite nitride boron-diamond" with the processed materials, the friction coefficient $\mu$ was taken as the main parameter. Analysis of the basic patterns of change of the coefficient of friction depending on various factors makes it possible to evaluate the material in comparison with other materials of this class and purpose [24]-[27]. Fig. 2 shows the dependences of the coefficient of friction $\mu$ on the sliding speed $V$ of the indenter from the composite material of the system "wurtzite boron nitride - diamond" on hardened steel 100Cr6 DIN 17230 (HRC 61...63) - curve $a$, and cast iron GG-20 DIN 1691 (HB 170...200) - curve $b$.

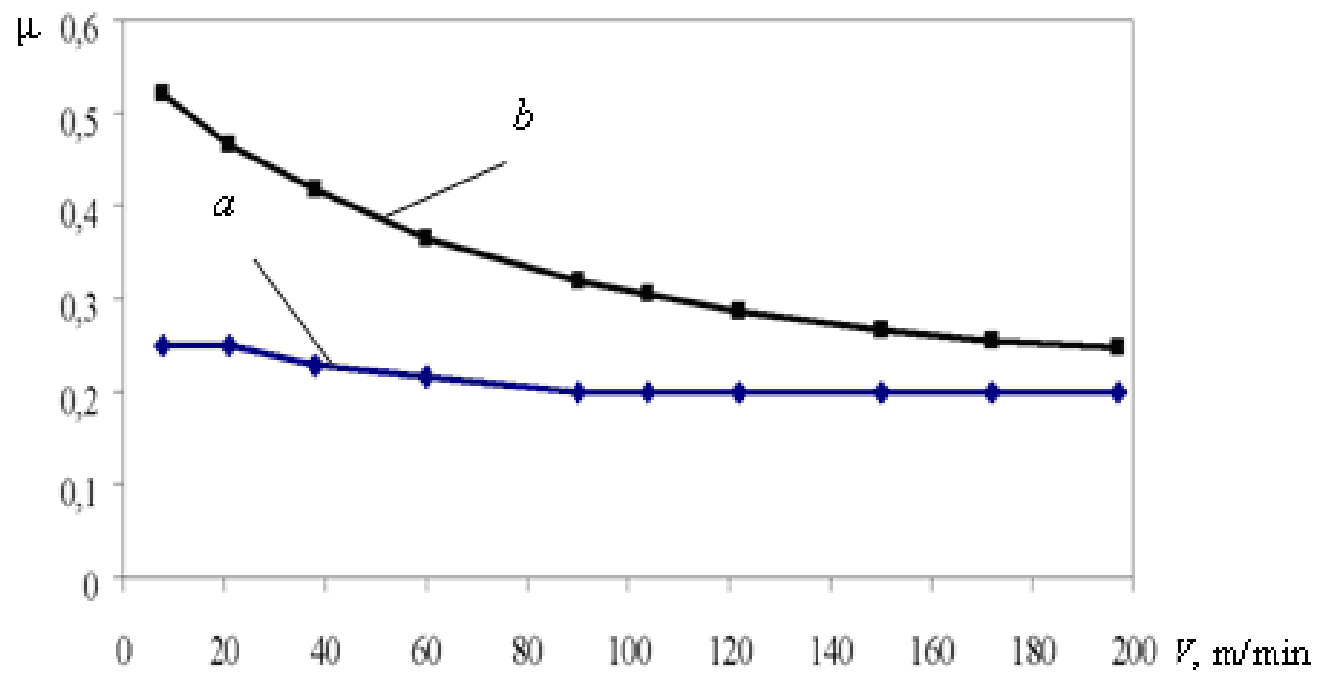

Fig. 2. Dependences of the coefficient of friction $\mu$ on the sliding speed $V$ of the indenter from the composite on steel SHX15 (a) and cast iron MF 21-40 (b) at $q=50 \mathrm{kgf} / \mathrm{mm}^{2}$

They indicate that the nature of the change in the coefficient of friction is almost the same for different materials. At low speeds, a larger value of the coefficient of friction $\mu$ is observed in the pair of composite - cast iron, and for the pair of composite-hardened steel 100Cr6, it is smaller. 


\section{Influence of Diamond Component Based on Wurtzite Boron Nitride on Wear Resistance of ...}

Analysis of the curves shows that the coefficient of friction $\mu$ decreases with increasing strength characteristics of machined materials, with increasing cutting speed the difference in the value of the coefficient of friction decreases, indicating the same mechanism of friction at high contact temperatures of friction pairs occurring at high cutting speeds [23]-[25].

Comparing the dependences $\mu=f(V)$ for the composite "BN $\mathrm{w}_{\mathrm{w}}$ - diamond" and composite 10 (Fig. 3) we observe the same nature of their change, but the value of the friction coefficient of the composite "BN $\mathrm{N}_{\mathrm{w}}$ - diamond" is smaller, especially at low values of cutting speed.

This mechanism of friction is obviously characteristic of all materials paired with the composite "wurtzite boron nitride - diamond", but this maximum is weak and is mostly in the region of low friction velocities. The study of the nature and features of the wear process and the stability of the cutting tool made of composite systems " $\mathrm{BN}_{\mathrm{w}}$ - diamond" was carried out by longitudinal turning of samples of hardened steel with a hardness of HRC 61...63. It is established that turning of hardened steels is accompanied by wear of the cutter on both the rear and front surfaces, wear on the rear surface is characterized by the presence of sawtooth grooves, the direction of which coincides with the direction of the cutting speed vector, which is characteristic of wear of composite 10 tool [5], [23]-[25], [32].

The amount of wear was determined as the average of the five tests of each plate. Table 1 shows the optical image of the nature of wear of the cutting edge of plates of different composition of the composite " $\mathrm{BN}_{\mathrm{w}}$ - diamond" in the mode of continuous smooth turning and turning with impact steel 100Cr6 DIN 17230 (HRC 61...63).

Optical image of the cutting edge of the plates of the composite " $B N_{w}-$ diamond"

\begin{tabular}{|c|c|c|c|c|}
\hline \multirow{4}{*}{$\begin{array}{c}\text { Composite } \\
\text { type }\end{array}$} & \multirow{4}{*}{$\begin{array}{c}\text { Composite } \\
\text { composition: } \\
\text { "BN } \mathrm{B}_{\mathrm{w}}+\text { diamond" }\end{array}$} & \multirow{4}{*}{$\begin{array}{l}\text { Sintering } \\
\text { temperature }\end{array}$} & \multicolumn{2}{|c|}{ Operating conditions of the plate } \\
\hline & & & Turning with a blow & Smooth turning \\
\hline & & & \multicolumn{2}{|c|}{ Cutting modes } \\
\hline & & & $V=75 \mathrm{~m} / \mathrm{min}, t=0.2 \mathrm{~mm}$ & $V=150 \mathrm{~m} / \mathrm{min}, t=0.5 \mathrm{~mm}$ \\
\hline 1 & $\mathrm{BN}_{\mathrm{w}}+0.1 / 0 \mu \mathrm{m}$ & $T=1600^{\circ} \mathrm{C}$ & & \\
\hline 2 & $\mathrm{BN}_{\mathrm{w}}+0.1 / 0 \mu \mathrm{m}$ & $T=2000^{\circ} \mathrm{C}$ & & \\
\hline 3 & $\mathrm{BN}_{\mathrm{w}}+10 / 7 \mu \mathrm{m}$ & $T=1800^{\circ} \mathrm{C}$ & & \\
\hline & & & $400 \mathrm{MkM}$ & \\
\hline
\end{tabular}

The table shows the nature of wear of cutting plates of composites of three types: based on $\mathrm{BN}_{\mathrm{w}}$ with diamonds of static synthesis $0.1 / 0 \mu \mathrm{m}$ (type 1 , type 2 ), which are obtained at different sintering temperatures, as well as composite based on wurtzite boron nitride and diamonds static synthesis of 10/7 $\mu \mathrm{m}$ (type 3 ). 
Fig. 4 shows the values of wear of cutting plates made of composite " $\mathrm{BN}_{\mathrm{w}}-$ diamond" at continuous smooth turning $(a)$ depending on the cutting modes $V=150 \mathrm{~m} / \mathrm{min}, T=0.5 \mathrm{~mm}$ and turning with impact (b) at modes $V=75 \mathrm{~m} / \mathrm{min}, t=0.2 \mathrm{~mm}$.

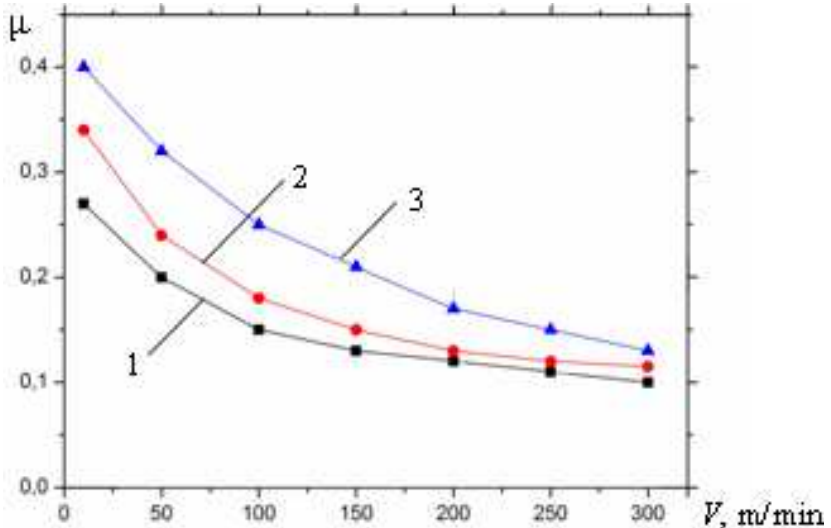

Fig. 3. Dependences of the friction coefficient $\mu$ on the sliding speed $V$ on steel 100Cr6 DIN 17230: 1 - composite " $\mathrm{BN}_{\mathrm{w}}$ - diamond $0.1 / 0$ ";

2 - composite " $\mathrm{BN}_{\mathrm{w}}$ - diamond 10/7"; 3 - composite 10

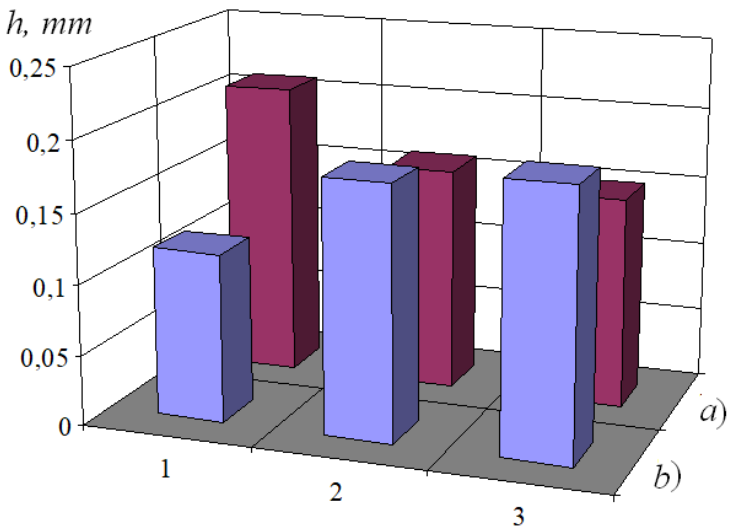

Fig. 4. Dependence of the amount of wear of cutting plates of different types of composite

" $\mathrm{BN}_{\mathrm{w}}$ - diamond" with continuous smooth turning $(a)$ with $V=150 \mathrm{~m} / \mathrm{min}, t=0.5 \mathrm{~mm}$ and when turning with impact (b) with $V=75 \mathrm{~m} / \mathrm{min}, t=0.2 \mathrm{~mm}$ : 1 - composite "type 1"; 2 - "type 2"; 3 - "type 3"

Experimental studies of cutting tools based on composite material of the system "wurtzite boron nitride - diamond" showed that the effectiveness of the composite is determined by the composition and conditions of its production at high pressures and temperatures.

\section{Conclusions}

As a result of the experiments, the following conclusions can be stated.

1. The presence of the diamond component in the composite significantly affects the contact temperature in the cutting zone due to the set of heat pulses that occur at the vertices of the contact microroughnesses, contributing to heat dissipation, which causes higher tool stability in constant contact with the material.

2. When processing hardened steel with the presence of shock loads, the best performance indicators were found in samples obtained at $T=1600^{\circ} \mathrm{C}$, which contained diamonds of static synthesis of $0.1 / 0 \mu \mathrm{m}$.

3. This result can be explained by the fact that the temperature conditions of formation of the matrix component of the composite based on wurtzite boron nitride contributed to obtaining a two-phase state, which provides high resistance of the composite material to significant dynamic loads. In this case, as for the single-phase composite, the presence of a diamond component in the material to some extent affects the value of the contact temperature in the cutting zone.

4. When processing hardened steel 100Cr6 DIN 17230 in the mode of continuous turning, the best results showed samples that included diamonds of static synthesis of $10 / 7 \mu \mathrm{m}$ and were obtained at $T=1800^{\circ} \mathrm{C}$, i.e. in the temperature range that promotes collective recrystallization of the material, as the matrix component is fully represented sphalerite boron nitride.

5. The stability of the tool in the conditions of smooth turning is significantly affected by the diamond component in the composite due to heat dissipation in contact with the processed material, and in the processing of hardened steels with shock loads the phase state of the matrix component of the composite plays a decisive role.

\section{References}

[1] Instrumenty iz sverkhtverdykh materialov [Tools made of superhard materials], N. V. Novikova, and S. A. Klimenko, Eds. Moscow, Russia: Mashinostroyeniye Publ., 2014. [in Russian]. 


\section{Influence of Diamond Component Based on Wurtzite Boron Nitride on Wear Resistance of ...}

[2] V. P. Astakhov, "Machining of Hard Materials - Definitions and Industrial Applications", in Machining of Hard Materials. London, UK: Springer, 2011, pp. 1-32.

[3] T. Halpin, G. Byrne, J. Barry, E. Ahearne, "The performance of polycrystalline cubic boron nitride tools in continuous, semi-interrupted, and interrupted hard machining", Proceedings of the Institution of Mechanical Engineers, Part B: Journal of Engineering Manufacture, vol. 223, issue 8, pp. 947-953, 2009.

[4] G. V. Borovskij, B. E. Pini, E. A. Khachikyan, "Vysokoproizvoditelnaya preczizionnaya obrabotka zakalennykh stalej malorazmernym instrumentom iz kubicheskogo nitrida bora (KNB)" ["High-performance precision machining of hardened steels with a small-sized tool made of cubic boron nitride (CBN)"], Izvestiâ MGTU “MAMI”, no. 2 (14), pp. 30-38, 2012. [in Russian].

[5] K. S. Barandych, S. P. Vysloykh, V. S. Antonyuk, "Ensuring fatigue life of parts during finish turning with cubic boron nitride tools", Journal of Superhard Materials, vol. 40, issue 3, 206-215, 2018.

[6] Y. B. Guo, M. E. Barkey, "FE-simulation of the effects of machining-induced residual stress profile on rolling contact of hard machined components", International Journal of Mechanical Science, vol. 46, issue 3, pp. 371-388, March 2004.

[7] Y. A. Fedoran, V. M. Volkogon, V. S. Antonyuk, S. K. Avramchuk, "Vliyanie strukturnogo sostoyaniya PSTM na osnove vyurczitnogo nitrida bora na ikh effektivnost pri tonkom tochenii zakalennykh stalej" ["Influence of the structural state of PSHM based on wurtzite boron nitride on their efficiency in fine turning of hardened steels"], Nanoengineering, no. 5, pp. 28-34, 2014. [in Russian].

[8] C.-I. Balan, "Factors influencing surface integrity in hard machining of steels - A review", International Journal of Scientific and Engineering Research, vol. 6, issue 5, pp. 38-43, May 2015.

[9] T. Halpin, G. Byrne, J. Barry, "The performance of PCBN in hard turning”, Industrial Diamond Review, vol. 65, issue 4, pp. 52-60, January 2005.

[10] N. Ånmarka, T. Björk, A. Ganea, P. Ölund, S. Hogmark, A. Karasev, P. G. Jönsson, "The effect of inclusion composition on tool wear in hard part turning using PCBN cutting tools", Wear, vols. 334-335, pp. 13-22, July 2015.

[11] J. Barry, G. Byrne, "Cutting tool wear in the machining of hardened steel, part 2: cubic boron nitride cutting tool wear", Wear, vol. 247, issue 2, pp. 152-160, 2001.

[12] C. A. Klimenko, A. S. Manokhin, M. Yu. Kopeikina, S. A. Klimenko, Yu. M. Melnichuk, A. A. Chumak, Vysokoproizvoditelnaya chistovaya obrabotka detalej iz stalej vysokoj tverdosti [High performance finishing of high hardness steels]. Kyiv, Ukraine: V. Bakul Institute for Superhard Materials of the National Academy of Sciences of Ukraine, 2018. [in Russian].

[13] Y. K. Chou, C. J. Evans, M. M. Barashb, "Experimental investigation on cubic boron nitride turning of hardened AISI 52100 steel”, Journal of Materials Processing Technology, vol. 134, issue 1, pp. 1-9, March 2003.

[14] S. V. Grubyy, V. V. Lapshin, "Issledovaniye rezhushchikh svoystv reztsov iz nitrida bora" ["Research of cutting properties of boron nitride cutters”], Science and Education, no. 06, pp. 61-76, June 2012.

[15] G. C. Benga, A. M. Abrao, "Turning of hardened 100Cr6 bearing steel with ceramic and PCBN cutting tools", Journal of Material Processing Technology, vols. 143-144, pp. 237-241, December 2003.

[16] V. M. Volkogon, V. S. Antonyuk, "The effect of graphite-like boron nitride on the formation of residual stresses, strength, and performance of materials based on wurtzitic boron nitride", Journal of Superhard Materials, vol. 23, no. 5, pp. 50-53, 2001.

[17] P. A. Vityaz, V. T. Senyut, "Sintez i primenenie nanostrukturnyh sverhtverdyh materialov instrumentalnogo naznachenija" ["Synthesis and application of nanostructural superhard materialsof tool appointment"], Proceedings of the National Academy of Sciences of Belarus, Physical-Technical Series, no.3, pp. 6076, 2015. [in Russian].

[18] V. S. Antonyuk, E. B. Soroka, V. I. Kalinichenko, "Providing adhesion strength for a substrate-coating system under contact loading”, Journal of Superhard Materials, vol. 30, no. 2, pp. 133-138, 2008.

[19] Y. K. Chou, "Hard turning of M50 steel with different microstructures in continuous and intermittent cutting", Wear, vol. 255, issues 7-12, pp. 1388-1394, 2003.

[20] V. S. Antonyuk, "Formation of wear-resistant antifriction composite coatings reinforced with ultradispersed diamond”, Journal of Superhard Materials, vol. 20, no. 4, pp. 66-69, 1998.

[21] F. Klocke, E. Brinksmeier, K. Weinert, "Capability profile of hard cutting and grinding processes", CIRP Annals, vol. 54, issue 2, pp. 22-45, 2005. 


\section{Volodymyr Volkogon, Svitlana Avramchuk, Yuriy Fedoran, Andrii Kravchuk, et al.}

[22] S. R. Das, D. Dhupal, A. Kumar, "Experimental investigation on cutting force and surface roughness in machining of hardened AISI 52100 steel using cBN tool”, International Journal of Machining and Machinability of Materials, vol. 18, no. 5/6, pp. 501-521, 2016.

[23] Sverkhtverdye materialy. Poluchenie i primenenie [Superhard materials. Obtaining and application], N. V. Novikova, Ed., Vol. 5: Obrabotka materialov lezvijnym instrumentom [Processing of metals with a razor tool], S. A. Klimenko, Ed. Kyiv, Ukraine: V. Bakul Institute for Superhard Materials of the National Academy of Sciences of Ukraine, 2006. [in Russian].

[24] V. A. A. De Godoy, A. E. Diniz, "Turning of interrupted and continuous hardened steel surfaces using ceramic and CBN cutting tools”, Journal of Materials Processing Technology, vol. 211, issue 6, pp. 1014-1025, 2011.

[25] A. E. Diniz, D. M. Gomes, A. Braghini, “Turning of hardened steel with interrupted and semi-interrupted cutting”, Journal of Materials Processing Technology, vol. 159, issue 2, pp. 240-248, 2005.

[26] Y. Huang, Y. K. Chou, S. Y. Liang, "CBN tool wear in hard turning: a survey on research progresses", The International Journal of Advanced Manufacturing Technology, no. 35, pp. 443-453, 2007.

[27] M. A. Yallese, K. Chaoui, N. Zeghib, L. Boulanouar, J.-F. Rigal, "Hard machining of hardened bearing steel using cubic boron nitride tool”, Journal of Materials Processing Technology, vol. 209, issue 2, pp. 1092-1104, January 2009.

[28] A. V. Kurdyumov, A. N. Pilyankevich, Fazovye prevrashheniya v uglerode $i$ nitride bora [Phase transformations in carbon and boron nitride]. Kyiv, Ukraine: Naukova dumka Publ., 1979. [in Russian].

[29] V. M. Volkogon, M. A.Vasylkovska, I. I. Tymofeeva, S. K. Avramchuk, A. V. Kravchuk, I. I. Buzhanska, Y. A. Fedoran, T. V. Pavlychuk, V. S. Antonyuk, "Interaction during barothermal processing of wurtzite boron nitride with diamonds obtained under different synthesis conditions", Journal of nano- and electronic physics, vol. 11, no. 6, Paper ID 06014, 2019.

[30] A. A. Shul'zhenko, A. N. Sokolov, M. G. Loshak, L. I. Aleksandrova, N. I. Zaika, "Physico-mechanical properties and structure of diamond polycrystalline composite materials produced from variously dispersed powders", Journal of Superhard Materials, vol. 30, issue 1, pp. 23-27, 2008.

[31] V. M. Volkogon, S. K. Avramchuk, A. V. Kravchuk, T. V. Pavlychuk, V. S. Antonyuk, K. I. Avramchuk, "The influence of the phase composition of the b-n-c system composition material on its physical-mechanical and tribological characteristics", Journal of nano- and electronic physics, vol. 12, no. 3, Paper ID 03035, 2020.

[32] Y. Huang, S. Y. Liang, "Modeling of CBN Tool Flank Wear Progression in Finish Hard Turning", Journal of Manufacturing Science and Engineering, vol. 126, no. 1, pp. 98-107, 2004. 